\title{
Analysis of Proteins Bound to Contact Lenses
}

Katherine M Beglinger, Laura Zielewicz, Armand G Ngounou Wetie and Costel C Darie*

Biochemistry \& Proteomics Group, Department of Chemistry \& Biomolecular Science, Clarkson University, 8 Clarkson Avenue, Potsdam, NY, 13699-5810, USA

\begin{abstract}
The purpose of this study was to determine whether there are any proteins that attach to contact lenses that can be removed by cleaning solutions and if so, whether it is possible to quantify them by Bradford assay and identify them by nanoliquid chromatographytandem mass spectrometry (nanoLC-MS/MS). Our results indicate that the contact lenses indeed contain equal amounts of proteins, as determined by quantitative Bradford assay. NanoLC-MS/MS analysis led to the identification of several proteins, including lipocalin-1, lysozyme and tryptophan 5-hydroxylase. The significance of our findings is discussed.
\end{abstract}

Keywords: Biochemistry; Mass spectrometry; Proteomics

\section{Introduction}

A major problem for people who wear contact lenses is the accumulation of debris on the lenses, such as proteins. This can often lead to discomfort or damage of the lenses. According to one study there is a significant amount of protein accumulation on contact lenses after extended wear [1]. Proteins found to accumulate on lenses are albumin, PMFA, IgG, IgA, lactoferrin and subunits of protein $\mathrm{G}$ in all samples [2]. These proteins are known as "tear film proteins" and they are found within the aqueous layer of the eye. The main functions of these proteins are to cleave cell wall constituents to kill bacteria (lysozymes), scavenge lipids from the cornea surface (tear lipocalin), and to inhibit microbe action by competing with them for iron (lactoferrin) [3]. However, when these proteins accumulate extensively on the lenses, people begin to feel more discomfort [2].

The purpose of this study was to determine whether there are proteins on the contact lenses and if so, to also determine the relative concentration of these proteins in the contact lens cleaning solution using the Bradford assay [4]. We also sought to identify the most abundant proteins on the contact lenses using nanoLC-MS/MS. NanoLC-MS/MS is a mass spectrometry-based method known to determine the amino acid sequence of peptides and proteins [5-16]. We found that when we use different cleaning solutions, the concentration of proteins removed from the contact lenses is very similar. NanoLCMS/MS analysis led to identification of several proteins, including lipocalin-1, lysozyme, tryptophan 5-hydroxylase and human keratins. The significance of this study is discussed.

\section{Methods}

\section{Materials}

Three types of contact lenses solutions were used (solution C, solution $\mathrm{E}$ and solution $\mathrm{B}$ ) to clean two different types of contact lenses ( $\mathrm{K}$ and $\mathrm{L}$ ). The resulting letter combination shown in Table 1 (i.e. LC, LE, LB) represent contact lenses $L$ washed with solution C (LC), E (LE) or B (LB). The initial volume of pooled samples were measured (Table 1), dried using a SpeedVac concentrator and then re-suspended in 500 $\mu \mathrm{L}$ of water.

\begin{tabular}{|c|c|c|c|c|}
\hline Sample & $\begin{array}{c}\text { Volume } \\
(\mathbf{m l})\end{array}$ & $\begin{array}{c}\text { Absorbance } \\
\text { at 595 } \mathbf{~ n m}\end{array}$ & $\begin{array}{c}\text { Protein Concentration } \\
\mathbf{( m g / m l )}\end{array}$ & $\begin{array}{c}\text { Total protein present } \\
\text { in sample (mg) }\end{array}$ \\
\hline LC & 46 & 0.032 & 0.032543003 & 1.49697815 \\
\hline LE & 23 & 0.028 & 0.030993336 & 0.712846738 \\
\hline LB & 15 & 0.002 & 0.020920502 & 0.313807531 \\
\hline KC & 44 & 0.008 & 0.023245002 & 1.022780102 \\
\hline KE & 16 & 0.02 & 0.027894003 & 0.446304045 \\
\hline KB & 18 & 0.029 & 0.031380753 & 0.564853556 \\
\hline
\end{tabular}

Table 1: Volume, absorbance, protein concentration and total protein content of each sample.
Protein Quantification was performed according to Bradford method [4].

\section{Protein fractionation and identification}

SDS-PAGE was performed according to Sokolowska I, et al. $[17,18]$. For LC-MS/MS analysis and protein identification, the gels were stained with Coomassie Blue dye. The protein bands that were observed on the gel were excised and digested by trypsin according to Petrareanu C, et al. [19-21]. The peptides mixtures were then extracted, concentrated and then analyzed by nanoLC-MS/MS, according to Roy U, Sokolowska I, et al. [19-22]. The MS raw data files were processed by Protein Lynx Global Server (PLGS 2.4, Waters Corp) and then the resulting pkl files were submitted to Mascot database search. The PLGS processing parameters and database search parameters are described in Petrareanu C, et al. [19-21]. The MS/MS spectra that led to identification of proteins were verified in the raw files by Mass Lynx software (version 4.1; Waters Corporation).

\section{Results and Discussion}

\section{Protein quantification}

Initially, we determined the concentrations of proteins present in each solution sample using the Bradford assay. Since each sample had different volumes, the total amount of protein in the sample was determined (Table 1). As observed, the highest amount of protein was detected in sample C (LC and $\mathrm{KC}$ ), with an average of $1.26 \mathrm{mg}$ protein, followed by sample $\mathrm{E}$ ( $\mathrm{LE}$ and $\mathrm{KE}$ ), with an average of 0.579 $\mathrm{mg}$ protein, and sample B (LB and $\mathrm{KB}$ ), with an average of $0.439 \mathrm{mg}$ protein. However, when protein concentration was investigated, no great difference was observed (Table 1) and the protein concentration ranged from $0.020-0.032 \mathrm{mg} / \mathrm{mL}$ in all samples. These data suggest that regardless of the solution used, the protein concentration in the solution that was used to clean the lenses is similar and consistent.

Protein fractionation and identification: SDS-PAGE and nanoLC-MS/MS analysis

To verify whether we can identify proteins in our samples, we

*Corresponding author: Costel C Darie, Biochemistry \& Proteomics Group Department of Chemistry \& Biomolecular Science, Clarkson University, 8 Clarkson Avenue, Potsdam, NY, 13699-5810, USA, Tel: 315-268-7763; Fax: 315-268-6610; E-mail: cdarie@clarkson.edu

Received October 30, 2013; Accepted December 03, 2013; Published December 10,2013

Citation: Beglinger KM, Zielewicz L, Wetie AGN, Darie CC (2013) Analysis of Proteins Bound to Contact Lenses. Mod Chem appl 1: 114. doi:10.4172/2329 6798.1000114

Copyright: (C) 2013 Beglinger KM, et al. This is an open-access article distributed under the terms of the Creative Commons Attribution License, which permits unrestricted use, distribution, and reproduction in any medium, provided the original author and source are credited. 
Citation: Beglinger KM, Zielewicz L, Wetie AGN, Darie CC (2013) Analysis of Proteins Bound to Contact Lenses. Mod Chem appl 1: 114. doi:10.4172/2329-6798.1000114

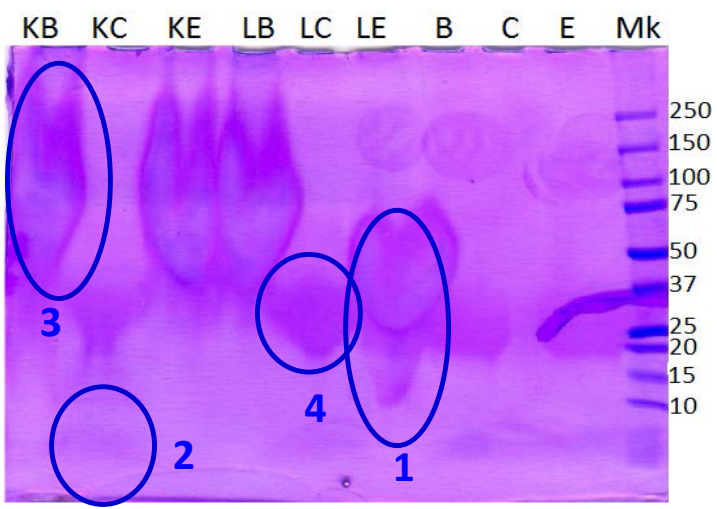

Figure 1: Coomassie blue stained SDS-PAGE gel. The washing solutions that were used to clean contact lenses were separated by SDS-PAGE and stained by Coomassie blue. Samples B, C and E were separated as samples set 1 (KB, KC \& KE) or as samples L (LB, LC, \& LE), or as protein-free samples (B, C \& E). The gel with the bands that were cut shown (right)
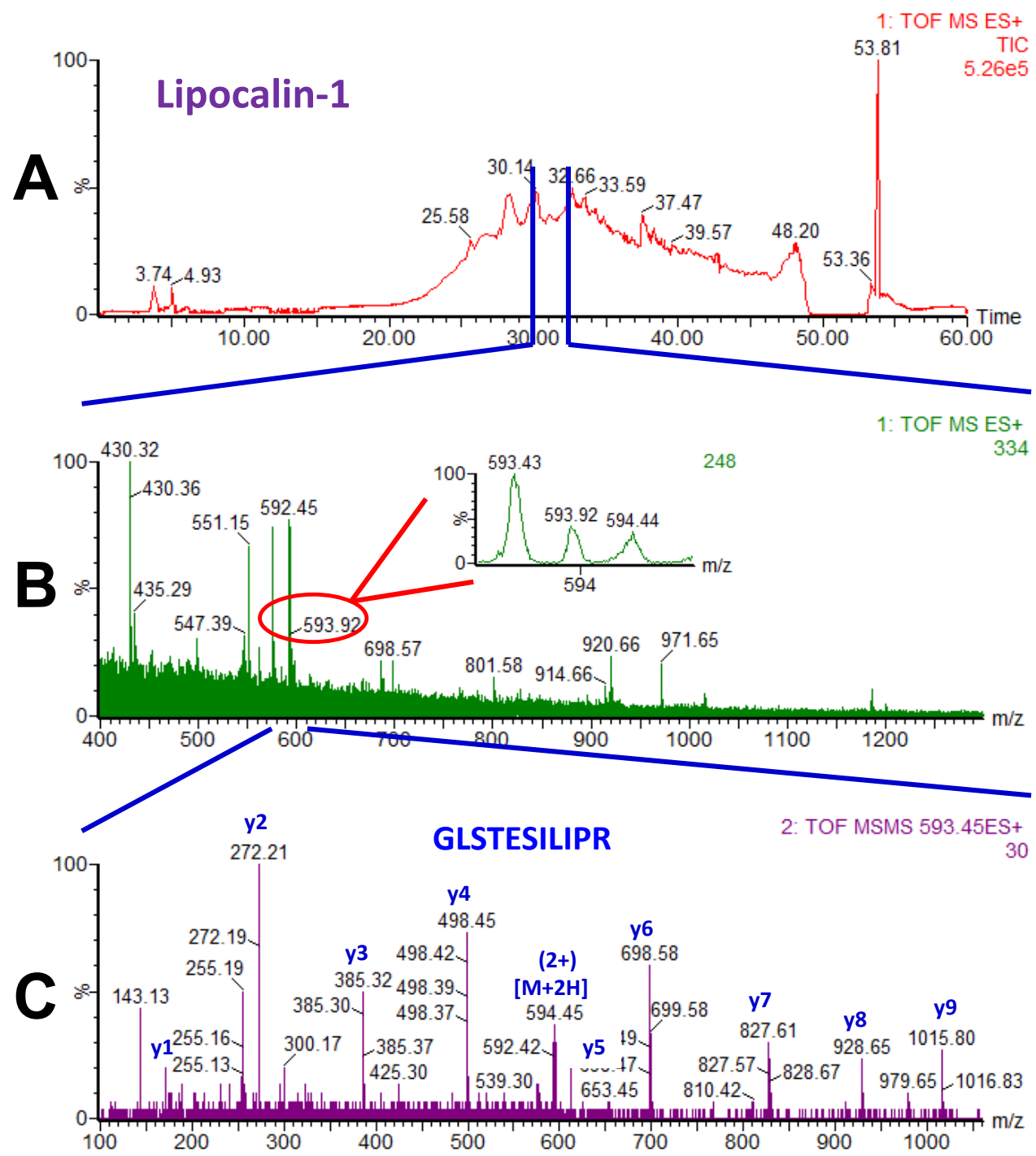

Figure 2: NanoLC-MS/MS analysis. (A) Total lon Chromatogram (TIC) of a 60 minutes HPLC gradient. (B) At elution time point $~ 31$ minutes, a MS spectrum was recorded. One of the doubly charged peaks (circled) with $\mathrm{m} / \mathrm{z}$ of 593.43 (insert), was selected for fragmentation and produced a MS/MS spectrum (C). Analysis of the fragment $b$ and $y$ ions led to identification of the peptide GLSTESILIPR, which is part of human lipocalin-1 protein. 
fractionated the samples by SDS-PAGE, stained the gel by Coomassie blue staining, and excised the gel pieces labeled 1-4, digested them by trypsin and subjected the resulting peptides mixtures to nanoLC-MS/ MS analysis. We chose those bands based on the intensity of the protein bands observed on the gel (all bands were very weakly stained). The SDS-PAGE is shown in Figure 1 (Figure 1).

NanoLC-MS/MS analysis of the peptide mixtures from the gel bands \#1-4 led to identification of several proteins, including lipocalin-1, lysozyme and tryptophan 5-hydroxylase. In addition, human keratin was also identified. Identification of lipocalin-1 and lysozyme is significant as they are either found in the eye or on the skin. Lipocalin and lysozymes are both part of the immune response and are found to be in the tear film of the eye. Keratin and tryptophan 5-hydroxylase are both found in the skin and could have been caused by touching the lenses to put them into the eye or possibly from being in contact with the sin or eyelashes near the eye. While it is known that lipocalin-1 and lysozyme are present in the tears, identification of keratins was also a good indication that trypsin digestion was successful, reason for which many times keratin is used as a positive control. The Total Ion Chromatogram (TIC) and the MS and MS/MS spectra that corresponded to a peptide which was part of lipocalin-1 are shown in Figure 2 (Figure 2).

\section{Conclusion}

In conclusion, contact lenses contain proteins that are removed by the cleaning solutions. NanoLC-MS/MS analysis led to identification of both the positive control proteins (keratins) and additional proteins, known to be in the tears (i.e. Lipocalin-1) or hands/gloves (keratins). Overall, the project was successful in both protein identification and quantification.

\section{Acknowledgement}

This work was supported by the Department of Chemistry \& Biomolecular Science. CCD thanks to supporters of the Biochemistry \& Proteomics Group, specifically to Mary Joyce, Robert Matloff, Ken Sandler, Bonhomie Wine Imports, Wolverine Packing $\mathrm{Co}$. and by the SciFund challenge contributors. Introduction of the mass spectrometry-based experiments in the Biochemistry \& Biotechnology laboratory was possible due to the kind support of CCD by Waters Corporation.

\section{References}

1. Zhao Z, Wei X, Aliwarga Y, Carnt NA, Garrett Q, et al. (2008) Proteomic analysis of protein deposits on worn daily wear silicone hydrogel contact lenses. Mol Vis 14: 2016-2024

2. Lin ST, Mandell RB, Leahy CD, Newell JO (1991) Protein accumulation on disposable extended wear lenses. CLAO J 17: 44-50

3. Wollensak G, Mur E, Mayr A, Baier G, Göttinger W, et al. (1990) Effective methods for the investigation of human tear film proteins and lipids. Graefes Arch Clin Exp Ophthalmol 228: 78-82.

4. Bradford MM (1976) A rapid and sensitive method for the quantitation of microgram quantities of protein utilizing the principle of protein-dye binding. Anal Biochem 72: 248-254.

5. Darie CC, Litscher ES, Wassarman PM (2008) Structure, processing, and polymerization of rainbow trout egg vitelline envelope proteins. Applications of Mass Spectrometry in Life Safety, NATO Science for Peace and Security Series A: Chemistry and Biology 23-36.

6. Darie CC, Shetty V, Spellman DS, Zhang G, Xu C, et al. (2008) Blue Native PAGE and mass spectrometry analysis of the ephrin stimulation-dependent protein-protein interactions in NG108-EphB2 cells. Applications of Mass Spectrometry in Life Safety, NATO Science for Peace and Security Series 3-22.
7. Aitken A (2005) Identification of post-translational modifications by mass spectrometry. The Proteomics Protocols Handbook 431-437.

8. Ngounou Wetie AG, Sokolowska I, Woods AG, Roy U, Loo JA, et al. (2013) Investigation of stable and transient protein-protein interactions: Past, present, and future. Proteomics 13: 538-557.

9. Ngounou Wetie AG, Sokolowska I, Woods AG, Wormwood KL, Dao S, et al (2013) Automated mass spectrometry-based functional assay for the routine analysis of the secretome. J Lab Autom 18: 19-29.

10. Sokolowska I, Gawinowicz MA, Ngounou Wetie AG, Darie CC (2012) Disulfide proteomics for identification of extracellular or secreted proteins. Electrophoresis 33: 2527-2536.

11. Guerrera IC, Kleiner O (2005) Applications of mass spectrometry in proteomics. Biosci Rep 25: 71-93.

12. Sokolowska I, Woods AG, Wagner J, Dorler J, Wormwood K, et al. (2011) Mass spectrometry for proteomics-based investigation of oxidative stress and heat shock proteins. Oxidative Stress: Diagnostics, Prevention, and Therapy 1083: 369-411.

13. Woods AG, Sokolowska I, Darie CC (2012) Identification of consistent alkylation of cysteine-less peptides in a proteomics experiment. Biochem Biophys Res Commun 419: 305-308.

14. Woods AG, Sokolowska I, Yakubu R, Butkiewicz, LaFleur M, et al. (2011) Blue native page and mass spectrometry as an approach for the investigation of stable and transient protein-protein interactions. Oxidative Stress: Diagnostics, Prevention, and Therapy 1083: 341-367.

15. Thome J, Coogan AN, Woods AG, Darie CC, Häßler F (2011) CLOCK Genes and Circadian Rhythmicity in Alzheimer Disease. J Aging Res 2011: 383091.

16. Woods AG, Sokolowska I, Taurines R, Gerlach M, Dudley E, et al. (2012) Potential biomarkers in psychiatry: focus on the cholesterol system. J Cell Mol Med 16: 1184-1195.

17. Sokolowska I, Ngounou Wetie AG, Roy U, Woods AG, Darie CC (2013) Mass spectrometry investigation of glycosylation on the NXS/T sites in recombinant glycoproteins. Biochim Biophys Acta 1834: 1474-1483.

18. Sokolowska I, Woods AG, Gawinowicz MA, Roy U, Darie CC (2012) Identification of a potential tumor differentiation factor receptor candidate in prostate cancer cells. FEBS J 279: 2579-2594.

19. Petrareanu C, Macovei A, Sokolowska I, Woods AG, Lazar C, et al. (2013) Comparative proteomics reveals novel components at the plasma membrane of differentiated HepaRG cells and different distribution in hepatocyte- and biliary-like cells. PLoS One 8: e71859.

20. Roy U, Sokolowska I, Woods AG, Darie CC (2012) Structural investigation of tumor differentiation factor. Biotechnol Appl Biochem 59: 445-450.

21. Sokolowska I, Dorobantu C, Woods AG, Macovei A, Branza-Nichita N, et al. (2012) Proteomic analysis of plasma membranes isolated from undifferentiated and differentiated HepaRG cells. Proteome Sci 10: 47.

22. Sokolowska I, Ngounou Wetie AG, Woods AG, Darie CC (2012) Automatic determination of disulfide bridges in proteins. J Lab Autom 17: 408-416. 